\title{
The Rapid Development Strategies of China New Energy under the
}

\section{Concept of Low-carbon Economy}

\author{
Fengbin $\mathrm{Xie}^{1}$ \\ ${ }^{1}$ China Center for Industry Security Research of Beijing Jiaotong University, Beijing, 100044, \\ China
}

Keywords: Low carbon, Low-carbon economy, New energy, International environment, Development Strategy

\begin{abstract}
Energy depletion and environmental degradation have become major threats to human sustainable development and low-carbon economy emerges at the historic moment. Development of low-carbon economy is suitable for the international background. Moreover, it is an inevitable choice of economic development and the only way to achieve sustainable development. To develop new energy industry has become the most effective and important way to promote the development of low-carbon economy in China. Based on the author's study and practice experience, this article analyzes the urgency and significance of developing low-carbon economy, and then the author studies international environment for the rapid development of China new energy under the concept of low-carbon economy. Finally, the author puts forward development strategies.
\end{abstract}

\section{Introduction}

Low-carbon economy guides to transform the economic development model to clean and efficient model by means of energy technology innovation. In essence, it is the efficient use of energy, the development of clean energy and the pursuit of green GDP. Its core is the innovation of energy technology and emission reduction technology, the innovation of industrial structure and institution and the fundamental change of human survival and development concept. The development of low-carbon economy is a positive commitment to environmental protection and is a requirement to achieve targets of national energy conservation, cost reduction and emission reduction. At the same time, it is an inevitable choice to adjust economic structure, improve energy efficiency, develop new industries, construct ecological civilization and achieve the goal of economic development and environmental protection. The development and utilization of new energy is undoubtedly the key to complete low-carbon revolution with the low-carbon economy as the core.

\section{The Urgency and Significance of Developing Low-carbon Economy}

Tackling global climate crisis needs Chinese efforts. UN report shows that in 2009, climate-related natural disasters lead to many displaced people, which is nearly four times as the number of war refugees. The increase emission of carbon dioxide in atmosphere is the major cause of global warming. A survey of the International Energy Agency shows that carbon dioxide emissions from the United States, China, Russia and Japan account for almost half of the global total. In view of this, to reduce carbon dioxide or other harmful gases emissions through the transformation from high-carbon economy to low-carbon economy has achieved consensus in the world. China, as one of the world's largest conventional energy consumers and high-carbon 
emission countries, should make its own contribution to addressing global climate crisis.

The shortage of conventional energy forces China to develop a low-carbon economy. Ministry of Land and Resources announced that a new round evaluation of national oil and gas resources shows that the quantity of China's prospective oil resources is 108.6 billion tons; the geological reserve is 76.5 billion tons and the recoverable resource is 21.2 billion tons. The quantity of China's perspective natural gas is 56 trillion cubic meters; the geological reserve is 35 trillion cubic meters and the recoverable resource is 22 trillion cubic meters. The website of People Daily reported on February 2, 2010 that the quantity of Chinese mainland recoverable oil is only exploited for 11 years and more than $50 \%$ of oil depends on foreign countries. The situation of natural gas is not optimistic. The shortage of conventional energy shows un-sustainability of its supply and to develop a low-carbon economy with new energy as the core is an inevitable choice.

Increasingly serious ecological damage and environmental pollution demand to accelerate the development of low- carbon economy. In 2014, China's energy consumption is total 4.26 billion tons of standard coal, with a growth of 2.2 percent over the previous year. Coal consumption fell by 2.9\%; consumption of crude oil increased by $5.9 \%$; natural gas consumption increased by $8.6 \%$; electricity consumption increased by $3.8 \%$. Coal consumption accounted for $66.0 \%$ of total energy consumption. Clean energy consumption accounted for $16.9 \%$ of total energy consumption, such as hydropower, wind power, nuclear power, natural gas and other clean energy. The country's ten thousand yuan GDP energy consumption fell by $4.8 \%$. The comprehensive energy consumption of a ton blister copper in industrial enterprises fell by 3.76 percent and the energy consumption of per ton steel fell by $1.65 \%$. Unit caustic soda comprehensive energy consumption fell by $2.33 \%$ and the comprehensive energy consumption per ton cement fell by $1.12 \%$. Standard coal consumption of thermal power per kWh reduced 0.67\%. World Bank estimates that China's annual economic loss due to ecological destruction and environmental pollution accounts for about $10 \%$ of the total GDP, one of the world's most serious air and water pollution in the world. Therefore, the pressure that the international community requires China to save energy and reduce emission is increasing.

\section{The International Environment for the Rapid Development of China New Energy}

British energy policies and implementation of new initiatives. Faced with global climate change, the United Kingdom decided to develop low-carbon economy. On July 15, 2009, British Department of Energy and Climate Change released a 220-page-long national strategy White Paper - The UK Low Carbon Transition, which proposed that in 2020 and 2050 UK carbon emissions will be reduced by $34 \%$ and $80 \%$ compared to 1990 on its way to greatly improve the energy efficiency and develop renewable energy, nuclear energy, carbon capture and storage and other clean energy technologies. At that time, $40 \%$ of its electricity comes from low-carbon energy sources (30\% from wind, wave, tidal energy and other renewable energy sources, $10 \%$ from nuclear power). It is ready to cut a half of gas imports; average cars carbon emissions will be reduced by $40 \%$. Promotion of new energy is the key to accomplish this goal, and wind energy is the key point in the UK new energy development. By 2020, the total UK wind power is expected to reach 33 billion watts.

Japan's new energy policy and Countermeasures. Japan lacks oil, coal, natural gas and other major energy and its energy self-sufficiency rate is only 4\%. Japanese 99.7\% oil, 97.7\% coal and 96.6\% natural gas depend on imports. After the two oil crisis in 1973 and 1978, the Japanese government and companies recognize the importance of developing alternative and new energy. From the mid-1970s, Japan began to promote the development and promotion of the use of new energy. As early as 1980, Japan enacted the Promotion Law of Development and Introduction of 
Oil-alternative Energy and set alternative energy development goals. Japan formulated preferential policies and specific measures to encourage and promote the development of new energy technologies. In May 2006, Japanese Ministry of Economy released New National Energy Strategy to guarantee energy security, the key points of which include: reduce oil dependency rate from the current $50 \%$ to $40 \%$ or less in 2030; promote nuclear energy; support strong energy companies to secure overseas energy supplies.

It can be summarized that Japan places the development of new energy as high as national security. Moreover, the legislation goes first and they conduct government-led research. The relative enterprises, institutions and company who conduct projects of the development of new energy technologies driven by the nation should get national financial aid. Furthermore, national finance should support to promote the development and popularization of new energy technologies. All these practices are worthy of learning.

Energy New Deal in America. After Barack Obama' assumption of duty, his first speech in parliament called for strengthening investment in clean energy and reiterated to double new energy production in three years. He said they would invest \$ 150 billion to fund alternative energy research over the next 10 years to reduced 50 tons of carbon dioxide emissions. He also promised to adopt new legislation to reduce greenhouse gas emissions by $80 \%$ by 2050 compared with 1990 and encourage consumers to buy energy-efficient cars with the tax credit. The series of initiatives to deal with the US recession and capture the new round of economic growth strategy commanding height is called New Energy Deal. Since July 2009, the US government has invested \$ 6.3 million to support basic bio-energy research and development projects in five states and provided \$ 52.5 million to support the research of concentrating solar power generation system which can provide low-cost electricity.

\section{The Rapid Development Strategies of China New Energy under the Concept of Low-carbon Economy}

Accelerate the formulation and implementation of new energy development plan. Since April, 2009, the Planning Division of National Energy Administration has led to formulate new energy industrial revitalization plan. In sub-sectors of the new energy industry, the wind power will be the focus in the future development and utilization of solar energy, which is lagged by technology. The new energy promotion plan was incorporated into the development and utilization of nuclear power and nuclear power development is expected to accelerate. It is expected that by 2020, China's total investment in the new energy field will reach more than 3 trillion yuan. The new energy industry development plan mainly includes the construction goal of new energy and relative investment. New energy development plan may significantly increase the original development goals: By 2020, China's new energy power generation installed capacity reaches 290 million kilowatts accounting for $17 \%$ of the total installed capacity with nearly 150 million kilowatts of wind power, 20 million kilowatts of photovoltaic power and 30 million kilowatts of biomass power.

Strengthen Public Finance Efforts for New Energy. New energy has high costs and investment risks with low industrialization and commercialization, so it is necessary for the government to make policies to support it. First, establish special fund of new energy development. The key support fields are solar, wind, biomass, tidal energy and other new energy development projects which investors are reluctant to invest and which cannot function well relying on market mechanism. Second, include it in the public budget and make direct investment. Finance can also be put directly into the new energy-related education and training. Third, improve the financial subsidies for new energy. First, continue to offer user subsidies. Give full play to 
consumption which can expand market and further promote the leading role of the production; Second, improve the investment subsidies. Integrate investment subsidies with the operation state of new energy business to stimulate enterprises to further improve technology and reduce costs. Fourth, offer tax preference to new energy industry to promote its development.

Broaden the financing channels and cultivate financing capacity of new energy industry. First, the government should increase direct investment to renewable energy and coordinate bank credit policies and fiscal policies simultaneously. Finance should increase loan with discounted interest and encourage commercial banks to expand credit scale and coverage, and give more preferential policies in terms of loan interest rate term. Second, reform the investment and financing system and diversify investors in new energy. Government should allow private capital to enter the field of new energy and try to create conditions to attract foreign capital to participate in China's new energy development. Third, refer to foreign experience to establish new energy fund system, which focus on renewable energy development projects, business development, and installation of product and equipment.

Promote scientific and technological innovation and reduce production costs of new energy. Inadequate scientific research and the lack of technological innovation are major obstacles to restrict China's new energy development. Enterprises should improve product percent conversion by upgrading existing technologies to further reduce costs and improve competitiveness. First, form linkage mechanism between the government and business to provide support for new energy technology research and development. The government should ensure investment in new energy technology research and development. Second, establish basic institutional framework of new energy technology innovation. The independent technology innovation system should take enterprises and scientific research institutions as the main body, take the market as the direction and combine industry, academia and research together. Third, select the right research, development and utilization of new energy technology. The forthcoming New Energy Development Plan gives priority to develop wind, solar, biomass and nuclear energy in China. In order to achieve this goal, first, we should solve manufacturing problems of large-scale wind power and biomass power generation equipment and have breakthroughs in key technologies of solar power and biomass liquid fuel production. China with nearly a quarter of the world's population has a strong consumer demand of nuclear energy and other clean energy. In order to ensure the safe use of nuclear energy, the innovation of nuclear technology is important. The government should promote industrialization and commercialization of clean energy through technical innovation.

\section{References}

[1] Zhang Hailong. A Study on the Development of China New Energy [D]. Jilin University, 2014.

[2] Wang Duoyun. A Study on the Development of New Energy from the Perspective of Low-carbon Economy [J]. Research On Development, 2010,04: 104-107.

[3] Ma Jimin. Development Strategies of Gansu New Energy under the Background of a Low-carbon Economy [J]. Gansu Social Sciences, 2010,05: 189-192.

[4] Wu Hui. A Study on the Development of New Energy Technology in Low-carbon Economic Environment [D]. Hefei University of Technology, 2012.

[5] Yu Jinda. A Study on the Development of New Energy and Government Behavior in Low-carbon Urban Construction [J]. Ecological Economy, 2015,05: 73-77. 